\title{
EFFECT OF THE BRAZILIAN THERMAL MODIFICATION PROCESS ON THE CHEMICAL COMPOSITION OF Eucalyptus grandis JUVENILE WOOD - PART 1: CELL WALL POLYMERS AND EXTRACTIVES CONTENTS
}

\author{
Djeison Cesar Batista ${ }^{1, ↔}$, Graciela Ines Bolzón de Muñiz ${ }^{2}$, José Tarcísio da Silva Oliveira ${ }^{1}$, \\ Juarez Benigno Paes ${ }^{1}$, Silvana Nisgoski ${ }^{2}$
}

\begin{abstract}
This article reports the first study of the influence of the Brazilian process of thermal modification called VAP HolzSysteme ${ }^{\circledR}$ on the chemical composition of Eucalyptus wood. Flatsawn boards of Eucalyptus grandis juvenile wood were tested for four treatment levels: untreated and thermally modified at final cycle temperatures of 140,160 and $180{ }^{\circ} \mathrm{C}$. Chemical analyses were carried out according to the standards of the Technical Association of the Pulp and Paper Industry and encompassed total extractives, insoluble lignin, holocellulose (cellulose + hemicelluloses) and solvent soluble extractives in water (cold and hot) and ethanol:toluene (1:2 v.v.) mixture. The chemical composition of thermally modified Eucalyptus grandis juvenile wood was significantly changed by the VAP HolzSysteme ${ }^{\circledR}$ process compared to untreated wood. Only the wood thermally modified at final cycle temperature of $180^{\circ} \mathrm{C}$ was significantly different for all the chemical analyses performed compared to untreated wood.
\end{abstract}

Keywords: Extractives content, holocellulose, insoluble lignin, VAP HolzSysteme ${ }^{\circledR}$.

\section{INTRODUCTION}

Eucalyptus wood from planted forests plays a very important role as raw material for the pulp and paper and charcoal industries in Brazil. On the other hand, its use as lumber for most added value products is insignificant, because fast growing eucalyptus juvenile wood's properties (high dimensional instability, high growing tensions, low durability and difficult of preservation) make it a difficult material for processing.

The great majority of studies about thermal modification have been carried out with softwoods, such as Picea abies and some species of Pinus spp. because of their economic importance for European countries, where the main industries of thermal modification are located. Of course, some important hardwoods are also processed in Europe, such as Populus spp., Fagus spp. and Fraxinus spp.

${ }^{1}$ Department of Forest and Wood Sciences, Federal University of Espírito Santo, Espírito Santo, Brazil.

${ }^{2}$ Department of Forest Engineering and Technology, Federal University of Paraná, Paraná, Brazil.

•Corresponding author: djeison.batista@ufes.br

Received: 15.05.2015 Accepted: 19.01.2016 
Some laboratorial scale studies have been performed about thermal modification of eucalyptus wood, mostly Eucalyptus globulus (Esteves et al. 2007a, Esteves et al. 2007b, Esteves et al. 2008) from Portugal, Eucalyptus grandis (Batista and Klitzke 2010, Batista et al. 2011, Calonego et al. 2010, Moura et al. 2012, Pessoa et al. 2006, Pincelli et al. 2002) and Eucalyptus saligna (Brito et al. 2008) from Brazil.

These studies have shown that eucalyptus wood has a great potential for thermal modification, improving mainly its properties of dimensional stability and decay resistance, what are key points for juvenile wood. Eucalyptus grandis (and its hybrids) is the most planted species in Brazil and we see a great potential for the commercialization of its thermally modified wood. That is why it has been the most studied species regarding the process of thermal modification.

In 2006 a Brazilian company started investigating thermal modification of wood, using Pinus sp., Eucalyptus sp. and Tectona grandis in its experiments. This research led to the development of an industrial process named VAP HolzSysteme ${ }^{\circledR}$ and the company is currently producing thermally modified Tectona grandis wood in industrial scale for indoor use.

Nevertheless, its research with other species is continuing and the first paper published about this Brazilian process of thermal modification studied Eucalyptus grandis juvenile wood anatomy (Batista et al. 2015).

This study is a continuing of Batista et al. (2015) and its aim was to evaluate the effect of the VAP HolzSysteme ${ }^{\circledR}$ process on the chemical composition of Eucalyptus grandis juvenile wood.

\section{MATERIAL AND METHODS}

\section{Wood material and thermal modification}

The Eucalyptus grandis W. Hill wood used in this study was from an 18-year-old stand (from seeds) planted in the municipality of Telêmaco Borba, Paraná state, southern Brazil. Five trees were felled; but for the study, we sampled only one juvenile corewood flatsawn board (30 x $200 \times 3,000$ $\mathrm{mm}$ ), without pith, cut from the first log of each tree. The rest of the wood was also brokendown and used to compose the batches.

We sampled only five boards for this study, which were trimmed into four equal parts in length, and equally distributed among the four treatment levels investigated: untreated wood (as control) and thermally modified wood at final cycle temperatures of 140,160 and $180^{\circ} \mathrm{C}$. These temperatures are the ones commonly used by the company where the research was carried out, and the thermally modified wood produced by the company is intended for indoor use.

Prior to thermal modification, the wood was seasoned until $15 \%$ of final moisture content, thereafter thermally modified according to the VAP HolzSysteme ${ }^{\circledR}$ process, in industrial scale equipment (steel cylinder $6 \mathrm{~m}^{3}$ of capacity), where one batch was processed separately for each final cycle temperature. Steam generated in a boiler was injected in the cylinder and worked as heat-transfer medium, what also limits oxidative processes, classifying the process as hygrothermal (Hill 2006). VAP HolzSysteme ${ }^{\circledR}$ is typically divided in five phases, which lengths approximately eight hours, with some more eight hours of cooling. The exact schedule is proprietary information, but a more detailed description of the process can be found in Batista et al. (2015). 


\section{Chemical analyses}

The chemical analyses were performed in the Wood Chemistry Laboratory of Federal University of Paraná, Brazil. First, the trimmed boards were milled in a Wiley mill and sieved to obtain a $40-60$ mesh fraction, which was used for chemical analyses according to the Tappi T264 cm-97 standard (Tappi 1997b). The sieved fractions were separated by board (five) and treatment level (four), resulting in five sampling unities by treatment level.

The sawdust used for the chemical analyses was taken from the sampling unities, resulting in five repetitions by treatment for the different analyses, which encompassed the determination of the content of total extractives, insoluble lignin, holocellulose (cellulose + hemicelluloses) and solvent-soluble extractives (cold water, hot water and ethanol:toluene).

The total extractives content was determined by successive Soxhlet extraction from approximately $2 \mathrm{~g}$ of each sample with different solvents in sequence: $200 \mathrm{ml}$ of the mixture ethanol:toluene (1:2 v.v.) for eight hours; $200 \mathrm{ml}$ of ethanol for six hours and $500 \mathrm{ml}$ of hot water for one hour.

Insoluble lignin was determined by the Klason method, according to Tappi T222 om-02 (Tappi 2002). The holocellulose content (cellulose + hemicelluloses) was measured by difference: holocellulose $=100 \%$ - (total extractives content + insoluble lignin content).

The soluble extractives content was determined using three solvents: the mixture of ethanol:toluene (1:2 v.v.), and water (hot and cold), according to Tappi T204 cm-97 and Tappi T207 cm-99 standards, respectively (Tappi 1997a, 1999).

\section{Statistical analysis}

Statistical analysis was performed according to a completely randomized design, with $95 \%$ confidence level. The effect of the treatments was checked by applying analysis of variance (ANOVA), with Bartlett's test used for its validation, which verifies a basic premise for the realization of ANOVA, the homogeneity of variances among treatments (Ribeiro-Júnior 2001). In cases of homogeneous variances, ANOVA was applied, while in cases of statistically significant difference between means, Tukey's multiple range test was used to determine which means were different.

If at least one of the variances was not statistically equal, the Kruskal-Wallis H-test was applied, which is a non-parametric method for ANOVA, for classification of a criterion or experiments with one factor, where generalizations can be made (Spiegel 1994). In this test, the original data of all treatments are increasingly ordered and receive scores, giving a mean score per treatment instead of an overall mean. Where at least one mean was not statistically equal ( $p$-value $<0,05$ ); a box-and-whisker plot was used to identify which were different. 


\section{RESULTS AND DISCUSSION}

The results of the chemical analyses can be seen in Table 1 .

\section{Holocellulose content}

The thermal modification temperatures used in this work $\left(140,160\right.$ and $\left.180{ }^{\circ} \mathrm{C}\right)$ were not high enough to cause mass loss of cellulose, according to previous information in the literature (Esteves, Graça and Pereira 2008; Esteves, Videira and Pereira 2011; Fengel and Wegener 1989; Sundqvist 2004).

Table 1. Chemical composition of untreated and thermally modified Eucalyptus grandis wood.

\begin{tabular}{|c|c|c|c|}
\hline Treatment & Holocellulose (\%) & Insoluble lignin (\%) & Total extractives content (\%) \\
\hline \multirow{2}{*}{ Untreated wood } & $69,38 \mathrm{a}$ & $28,31 \mathrm{~b}$ & $2,22 \mathrm{~b}$ \\
& $(2 \%)$ & $(3 \%)$ & $(26 \%)$ \\
\hline \multirow{2}{*}{$140^{\circ} \mathrm{C}$} & $67,51 \mathrm{~b}$ & $28,71 \mathrm{~b}$ & $3,60 \mathrm{~b}$ \\
& $(3 \%)$ & $(4 \%)$ & $(28 \%)$ \\
\hline \multirow{2}{*}{$160^{\circ} \mathrm{C}$} & $53,41 \mathrm{c}$ & $27,61 \mathrm{~b}$ & $19,04 \mathrm{a}$ \\
& $(2 \%)$ & $(6 \%)$ & $(8 \%)$ \\
\hline \multirow{2}{*}{$180^{\circ} \mathrm{C}$} & $52,80 \mathrm{c}$ & $31,21 \mathrm{a}$ & $15,85 \mathrm{a}$ \\
& $(2 \%)$ & $(6 \%)$ & $(9 \%)$ \\
\hline Bartlett's test & $1,16^{\text {ns }}$ & $1,21^{\text {ns }}$ & $1,24^{\text {ns }}$ \\
\hline ANOVA - F test & $415,79^{* *}$ & $10,90^{* *}$ & $494,30^{* *}$ \\
\hline
\end{tabular}

Averages followed by the same letter in a column do not differ significantly according to the Tukey test $(95 \%$ confidence level). Numbers in parentheses correspond to the coefficient of variation. ns: not statistically significant $(95 \%$ confidence level). $* *$ : statistically significant ( $99 \%$ confidence level)

Therefore, it is assumed that the process did not cause cellulose degradation, so the difference of holocellulose content among the treatments is believed to be attributed basically to the mass loss of hemicelluloses, which are the most thermally labile compounds of the cell wall structure (Fengel and Wegener 1989, Hill 2006, Stamm 1964, Sundqvist 2004).

As expected, untreated wood presented higher average holocellulose content than thermally modified wood, and the absolute averages had a constant pattern of reduction as the thermal modification temperature increased. However, the averages of the treatments at 160 and $180{ }^{\circ} \mathrm{C}$ were not significantly different.

The difference of holocellulose content between untreated wood and thermally modified wood at $140{ }^{\circ} \mathrm{C}$ was slight, just $2,7 \%$ (or 1,87 p.p.), but statistically significant, showing that even the lowest processing temperature used can cause significant mass loss of hemicelluloses. This result is in accordance to that reported by Sundqvist (2004), who explained that at $140{ }^{\circ} \mathrm{C}$ significant degradation of hemicelluloses already happens. It is known that the mass loss of hemicelluloses causes some desirable changes in the properties of thermally modified wood, such as improved dimensional stability and resistance to biodeterioration. According to the Finnish Thermowood Association (2003), even at $140{ }^{\circ} \mathrm{C}$ these desirable changings are noted in wood thermally modified by the ThermoWood ${ }^{\circledR}$ process.

On the other hand, the processing at 160 and $180{ }^{\circ} \mathrm{C}$ caused severe mass loss in Eucalyptus grandis wood. The holocellulose content declined $23,0 \%$ (15,97 p.p.) and 23,9\% (16,58 p.p.), respectively, in the wood treated at 160 and $180{ }^{\circ} \mathrm{C}$. It is known that such severe mass loss of hemicelluloses causes thermally modified wood to significantly lose its mechanical strength (Hill 2006). 
More research about the effect of the VAP HolzSysteme ${ }^{\circledR}$ thermal modification process on Eucalyptus grandis wood will soon carried out, encompassing physical and mechanical properties.

There are few published studies about the chemistry of thermally modified Eucalyptus grandis wood, but we found a very similar Brazilian study where the process was carried out in laboratory scale with a nitrogen $\left(\mathrm{N}_{2}\right)$ atmosphere (Moura, Brito and Silva Júnior 2012). The authors reported higher averages of holocellulose content for thermally modified 18-year-old (the same age as in this research) Eucalyptus grandis wood than we found, with 58,95 and 54,84\% respectively for treatments at 160 and $180{ }^{\circ} \mathrm{C}$. However the pattern of marked holocellulose content decrease with increasing temperature was the same in both studies.

\section{Insoluble lignin content}

The averages of insoluble lignin content of untreated and thermally modified wood at 140 and $160{ }^{\circ} \mathrm{C}$ did not differ significantly. But the average of the treatment at $180{ }^{\circ} \mathrm{C}$ was the highest and significantly different $(31,21 \%)$. According to Fengel and Wegener (1989), the lignin content of thermally modified wood starts to present an apparent (not real) increase from $140-150{ }^{\circ} \mathrm{C}$, but we only observed this phenomena starting at $180^{\circ} \mathrm{C}$. This result is in accordance with Sundqvist (2004), who reported that the processing temperature of $180^{\circ} \mathrm{C}$ is exactly the one where the degradation of hemicelluloses changes from "small" to "strong".

We can deduce that at $180{ }^{\circ} \mathrm{C}$, the hemicelluloses degradation is in an advanced stage when compared to lignin degradation, resulting in a higher proportion of the latter in the cell wall, so its content apparently increased in the treatment at $180^{\circ} \mathrm{C}$. This result is in accordance with those of other studies of Eucalyptus species (Brito et al. 2008, Esteves, Graça and Pereira 2008) and other species (Esteves et al. 2011, Hill 2006, Kamdem et al. 2002, Mohareb et al. 2012).

Although the averages of insoluble lignin content did not differ between untreated wood and the treatments at 140 and $160{ }^{\circ} \mathrm{C}$, it is reported in the literature that lignin degradation also occurs at these temperatures (Esteves et al. 2008, Esteves et al. 2011, Fengel and Wegener 1989, Hill 2006, Sundqvist 2004). So, it is possible that some degradation of lignin occurred in the present study, but at a small level when compared to the degradation of hemicelluloses and the increase in extractives content.

This can explain the non-significant differences of the averages of these three treatments. The same statistical behavior was reported by Moura et al. (2012), for the same treatments and species as in this study. The difference was that they thermally modified wood in laboratory scale, with an oxygen $\left(\mathrm{O}_{2}\right)$ atmosphere. But the same pattern of increasing lignin content was reported when they used a nitrogen atmosphere, when comparing untreated wood to thermally modified wood at 160 and $180^{\circ} \mathrm{C}$.

\section{Total extractives content}

Untreated wood presented the smallest absolute average of total extractives content $(2,22 \%)$, as expected, but it did not differ significantly from the average of the treatment at $140{ }^{\circ} \mathrm{C}(3,60 \%)$. Treatment at $160{ }^{\circ} \mathrm{C}$ presented the highest absolute average $(19,04 \%)$ but did not differ from the average of the treatment at $180{ }^{\circ} \mathrm{C}$. Thus, the averages of total extractives content were statistically divided into two groups among the treatments.

It is extensively reported in the literature that the extractives content of thermally modified wood increases compared to untreated wood due to degradation of hemicelluloses and lignin (Esteves et al. 2008, Esteves et al. 2011, Fengel and Wegener 1989, Hill 2006, Mohareb et al. 2012, Stamm 1964, Sundqvist 2004). In this particular situation, as can be seen in Table 1, the increase in the total extractives content of thermally modified wood occurred more by hemicelluloses degradation than by lignin degradation.

Figure 1 depicts the behavior of the average concentrations of holocellulose, insoluble lignin and total extractives for each treatment. The letters in the graph correspond to the statistical decision 
according to the Tukey test.

Figure 1 shows that the contents of holocellulose and total extractives are perfectly antagonistic in the samples in the untreated, 140 and $160{ }^{\circ} \mathrm{C}$ groups, meaning, where the holocellulose content is higher (untreated wood), the total extractives content is smaller and vice versa. Since the lignin content was not statistically different among these three treatments, we deduced that the increase in extractives content was mostly due to degradation of hemicelluloses, which turned into other substances, based on findings reported for Eucalyptus globulus wood (Esteves et al. 2008).

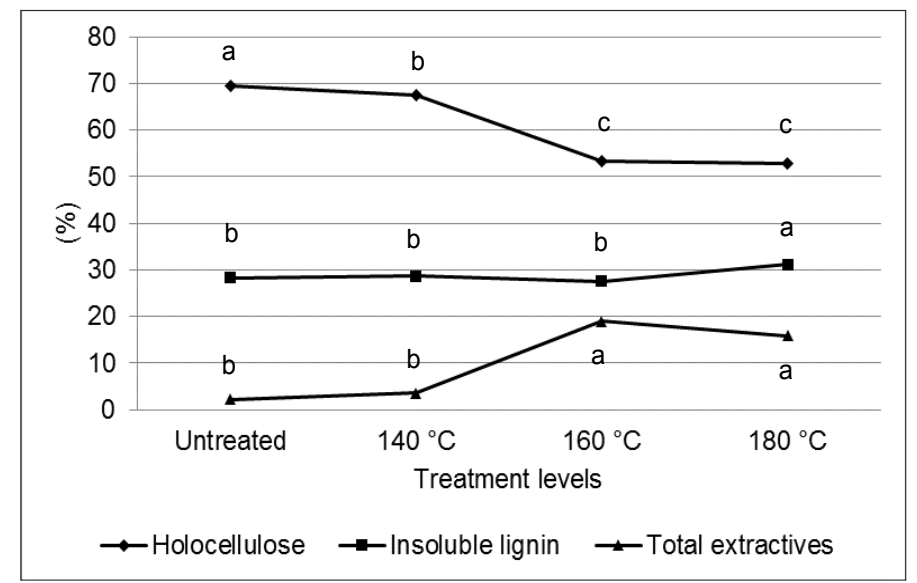

Figure 1. Behavior of the chemical composition of untreated and thermally modified Eucalyptus grandis wood.

We expected the holocellulose content of the wood treated at $180{ }^{\circ} \mathrm{C}$ to be significantly lower than that at $160{ }^{\circ} \mathrm{C}$, which did not happen. However, the lignin content of treatment at $180{ }^{\circ} \mathrm{C}$ was higher than that at $160{ }^{\circ} \mathrm{C}$ and the behavior of the absolute average of total extractives content was the contrary. Accordingly, it is possible to suppose that the apparent increase in lignin content of the treatment at $180^{\circ} \mathrm{C}$ was due to the decrease in the content of total extractives, which at this temperature might have been volatilized from the wood.

\section{Soluble extractives content}

Table 2 reports the results of soluble extractives content according to the different solvents used.

According to Bartlett's test, the variances of the treatments were statistically different for the ethanol:toluene and cold water treatments. However, the H-test showed there was a significant difference among the medians of the treatments for both solvents, so we used the box-and-whisker plots for median comparison, which are shown in Figure 2. 
Table 2. Averages of solubility in water (cold and hot) and ethanol:toluene by treatment.

\begin{tabular}{|c|c|c|c|}
\hline \multirow{2}{*}{ Treatment } & Cold water (\%) & Hot water (\%) & Ethanol:toluene (\%) \\
& & & $1,94 \mathrm{~A}$ \\
& $1,35 \mathrm{C}$ & $1,49 \mathrm{~dB}$ & $(20 \%)$ \\
\hline \multirow{2}{*}{ Untreated } & $(13 \%)$ & $(12 \%)$ & $3,16 \mathrm{~A}$ \\
& $2,54 \mathrm{C}$ & $3,02 \mathrm{cB}$ & $(26 \%)$ \\
\hline \multirow{2}{*}{$140^{\circ} \mathrm{C}$} & $(3 \%)$ & $(5 \%)$ & $16,69 \mathrm{~A}$ \\
& $10,02 \mathrm{C}$ & $12,53 \mathrm{aB}$ & $(12 \%)$ \\
\hline \multirow{2}{*}{$160^{\circ} \mathrm{C}$} & $(12 \%)$ & $(3 \%)$ & $15,64 \mathrm{~A}$ \\
& $3,88 \mathrm{C}$ & $6,02 \mathrm{bB}$ & $(14 \%)$ \\
\hline \multirow{2}{*}{$180^{\circ} \mathrm{C}$} & $(7 \%)$ & $(4 \%)$ & $2,01^{* *}$ \\
\hline Bartlett's test & $5,59^{* *}$ & $1,31^{\mathrm{ns}}$ & - \\
\hline ANOVA - F test & - & $2349,92^{* *}$ & $19,41^{* *}$ \\
\hline H test & $21,6^{* *}$ & - & \\
\hline
\end{tabular}

Averages followed by the same small letter in a column or the same capital letter in a row do not differ significantly according to the Tukey test ( $95 \%$ confidence level). Numbers in parentheses correspond to the coefficient of variation. ns: not statistically significant $(95 \%$ confidence level). $* *$ : statistically significant $(99 \%$ confidence level).
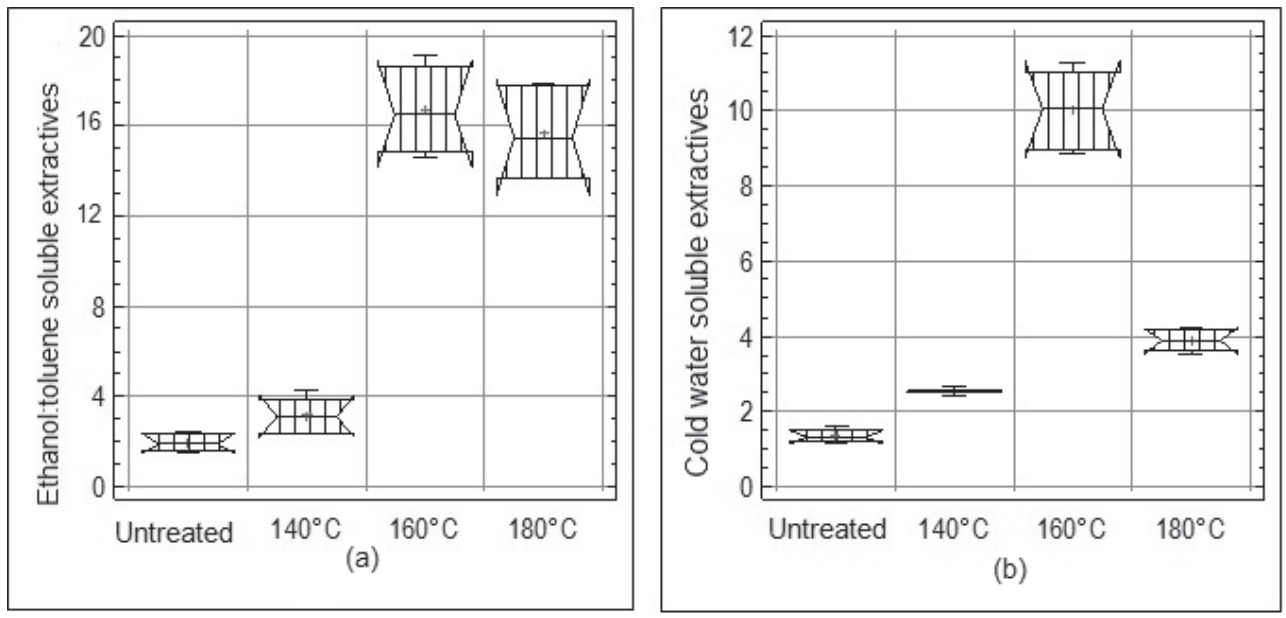

Figure 2. Comparison of medians: ethanol:toluene (a) and cold water (b) soluble extractives.

According to Figure 2b, there was no overlap of the areas of the notches of any box for the solvent cold water, which means that all the medians of the treatments were statistically different ( $95 \%$ confidence level). The same cannot be said for solubility in ethanol:toluene, where the areas of the notches of the boxes of the treatments at $160{ }^{\circ} \mathrm{C}$ and $180^{\circ} \mathrm{C}$ are superposed, indicating that their medians were not statistically different.

For the hot water soluble extractives it was possible to perform the Tukey test, which revealed that the averages of all treatments were statistically different. All the solvents had the same behavior, where extractives content increased steadily from untreated wood until thermally modified wood at $160{ }^{\circ} \mathrm{C}$, and decreased from the treatment at $160{ }^{\circ} \mathrm{C}$ to $180^{\circ} \mathrm{C}$. This decrease was more pronounced in the extractions with water and less so in the extraction with ethanol:toluene, as can be seen in Figure 3. 


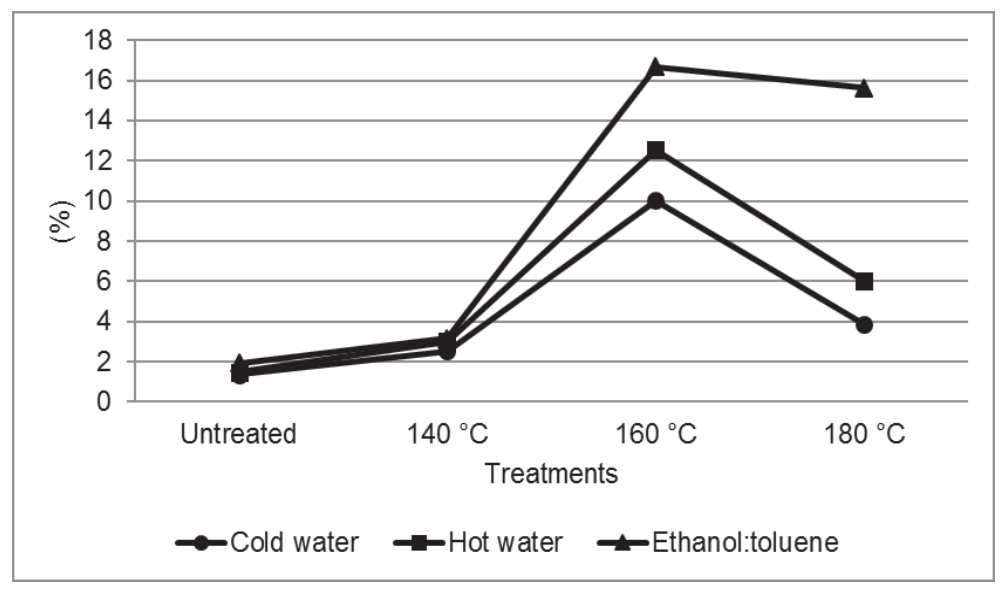

Figure 3. Variation in the extractives content according to different solvents.

We also performed the F-test to compare the strength of extraction among the solvents. It revealed there was a statistically significant difference of the averages $\left(\mathrm{F}=162,89^{* *}\right)$ in a same treatment for the different solvents (Table 2, capital letters in the same row). This analysis showed that for all treatments the solvent ethanol:toluene had higher strength of extraction, followed by hot water and cold water.

We expected this result because etanol:toluene has greater strength of extraction than water, because organic solvents naturally dissolve some substances that are insoluble in water (fats, fatty acids, sterols, steroids and long-chain alcohols), besides dissolving substances that are water soluble (phenolic compounds, glycosides, sugars, starch, proteins and inorganic salts) (Cruz et al. 2006, Esteves et al. 2008, Holmbom 1999, Silvério 2008, Sjöström 1993).

According to Kimo (1986), hot water as solvent in tests of Eucalyptus grandis wood samples dissolves the same substances as cold water, but dissolves extra fractions of polysaccharides through hydrolysis, mostly hemicelluloses. According to our results, this extra fraction was statistically significant.

Eucalyptus grandis wood has small amounts of water-soluble compounds (Kimo 1986). Other authors have reported that Eucalyptus grandis wood naturally has more compounds which are soluble in organic solvents, such as steroids, fatty acids, esters and long-chain alcohols (Barbosa et al. 2005, Cruz et al. 2006, Silvério 2008).

According to data presented in Table 2 and the graph shown in Figure 3, the increase in the extracted fraction between the treatments at $140{ }^{\circ} \mathrm{C}$ and $160{ }^{\circ} \mathrm{C}$ was higher for ethanol:toluene (13,53 p.p.) than for cold and hot water (7,48 and 9,51 p.p. respectively). These results indicate that from $160{ }^{\circ} \mathrm{C}$ compounds were produced derived from lignin and hemicelluloses that are soluble in ethanol:toluene but not (or less) soluble in water.

A similar comparison can be made for the decrease in the extracted fraction between the treatments at $160{ }^{\circ} \mathrm{C}$ and $180^{\circ} \mathrm{C}$. For ethanol:toluene, this decrease was 1,05 p.p. and for cold and hot water it was higher: respectively 6,14 and 6,02 p.p. We deduce that at $180^{\circ} \mathrm{C}$ an imbalance occurs between the volatilization and the production of compounds in the thermally modified wood, where water-soluble extracts are more volatile. 
The analysis of the soluble extractives of thermally modified Eucalyptus wood is complex at the temperatures used in this study. According to some authors who have studied Eucalyptus spp. (Brito et al. 2008, Esteves et al. 2008, Moura et al. 2012), when some extractives are volatilized, new substances are produced from degradation of hemicelluloses (mainly) and lignin, and part of these new substances are also volatilized. Further research will be carried out about the qualitative nature of the extractives of thermally modified Eucalyptus grandis wood.

Every forest species has its own particular characteristics regarding chemical composition of wood. The average contents of holocellulose, insoluble lignin and extractives for the thermally modified wood at $180{ }^{\circ} \mathrm{C}$ were all statistically different from those of untreated (or natural) Eucalyptus grandis wood. This result reinforces the idea that the thermal modification process turns the wood into a really modified product, different from the original raw material.

Following the same line, thermally modified wood at 140 and $160{ }^{\circ} \mathrm{C}$ also produced samples with different characteristics, but less chemically modified than that treated at $180^{\circ} \mathrm{C}$. It can be noted from changes in color and smell that thermally modified wood is a different product, but we would like to highlight that such physical changes are the result of the chemical modification imparted by the process.

\section{CONCLUSIONS}

The chemical composition of thermally modified Eucalyptus grandis juvenile wood was significantly changed by the Brazilian process of thermal modification VAP HolzSysteme ${ }^{\circ}$.

The holocellulose content decreased significantly with increasing temperature until the treatment at $160{ }^{\circ} \mathrm{C}$ and remained stable at $180{ }^{\circ} \mathrm{C}$.

The content of insoluble lignin remained constant in treatments at 140 and $160{ }^{\circ} \mathrm{C}$ and increased (apparently) only at the $180{ }^{\circ} \mathrm{C}$ treatment.

The content of total extractives remained constant at $140{ }^{\circ} \mathrm{C}$ and increased in the treatments at 160 and $180{ }^{\circ} \mathrm{C}$. The absolute content of extractives decreased at $180{ }^{\circ} \mathrm{C}$ in relation to $160{ }^{\circ} \mathrm{C}$, caused by volatilization.

Thermal degradation of hemicelluloses from the cell wall (which turned into other compounds or chains with smaller molecular mass) was the main factor responsible for the increase in the total extractives content in the treatments at 160 and $180{ }^{\circ} \mathrm{C}$.

Water-soluble extractives increased significantly with increasing temperature until $160{ }^{\circ} \mathrm{C}$ and decreased significantly from 160 to $180^{\circ} \mathrm{C}$. Hot water dissolved more substances than cold water.

Ethanol:toluene-soluble extractives increased significantly with increasing temperature until 160 ${ }^{\circ} \mathrm{C}$ and remained constant at $180{ }^{\circ} \mathrm{C}$. The ethanol:toluene mixture dissolved more substances than hot water, and water-soluble substances were more volatile at $180^{\circ} \mathrm{C}$ than those soluble in ethanol:toluene.

The same behavior was observed for the different solvents: cold and hot water and the ethanol:toluene mixture (1:2 v.v.).

Only the wood thermally modified at $180{ }^{\circ} \mathrm{C}$ was significantly different for all the chemical analyses performed when compared to untreated Eucalyptus grandis wood. 


\section{ACKNOWLEDGEMENTS}

The first author would like to thank CAPES - Coordenação de Aperfeiçoamento de Pessoal de Nível Superior (Office to Coordinate Improvement of University Personnel) for the research grant.

\section{REFERENCES}

Barbosa, L.C. de; Maltha, C.R.A.; Cruz, M.P. 2005. Composição química de extrativos lipofílicos e polares de madeira de Eucalyptus grandis. Revista Ciência \& Engenharia 15 (2): 13-20.

Batista, D.C.; Klitzke, R.J. 2010. Influência do tempo e temperatura de retificação térmica na umidade de equilíbrio da madeira de Eucalyptus grandis Hill ex Maiden. Scientia Forestalis 38 (86): 255-261.

Batista, D.C.; Paes, J.B.; Muñiz, G.I.B. de; Nisgoski, S.; Oliveira, J.T. da S. 2015. Microstructural aspects of thermally modified Eucalyptus grandis wood. Maderas. Ciencia y Tecnología 17 (3): 525532.

Batista, D.C.; Tomaselli, I.; Klitzke, R.J. 2011. Efeito do tempo e temperatura de modificação térmica na redução do inchamento máximo da madeira de Eucalyptus grandis Hill ex Maiden. Ciência Florestal 21 (3): 533-540.

Brito, J.O.; Silva, F.G.; Leão, M.M.; Almeida, G. 2008. Chemical composition changes in eucalyptus and pinus wood submitted to heat treatment. Bioresource Technology 99 (18):8545-8548.

Calonego, F.W.; Severo, E.T.D.; Furtado, E.L. 2010. Decay resistance of thermally-modified Eucalyptus grandis wood at $140{ }^{\circ} \mathrm{C}, 160{ }^{\circ} \mathrm{C}, 180^{\circ} \mathrm{C}, 200{ }^{\circ} \mathrm{C}$ and $220^{\circ} \mathrm{C}$. Bioresource Technology 101 (23):9391-9394.

Cruz, M.P.; Barbosa, L.C.A.; Maltha, C.R.A.; Gomide, J.L.; Milanez,A.F. 2006. Caracterização química do "pitch" em indústria de celulose e papel de Eucalyptus. Química Nova 29 (3): 459-466.

Esteves, B.M.; Marques, A.V.; Domingos, I.; Pereira, H. 2007a. Influence of steam heating on the properties of pine (Pinus pinaster) and eucalypt (Eucalyptus globulus) wood. Wood Science and Technology 41 (3): 193-207.

Esteves, B.M.; Domingos, I.; Pereira, H. 2007b. Improvement of technological quality of eucalypt wood by heat treatment in air at $170-200^{\circ}$ C. Forest Products Journal 57 (1/2): 47-52.

Esteves, B.M.; Graça, J.; Pereira, H. 2008. Extractive composition and summative analysis of thermally treated eucalypt wood. Holzforschung 62 (3): 344-351.

Esteves, B.M.; Videira, R.; Pereira, H. 2011. Chemistry and ecotoxicity of heat-treated pine wood extractives. Wood Science and Technology 45 (4): 661-676. 
Fengel, D.; Wegener, G. 1989. Wood: chemistry, ultrastructure, reactions. Walter De Gruyter, New York.

Finnish Thermowood Association. 2003. ThermoWood ${ }^{\circledR}$ handbook. Finnish Thermowood Association, Helsink.

Hill, C. 2006. Wood modification: chemical, thermal and other processes. John Wiley \& Sons, West Sussex.

Holmbom, B. 1999. Extractives. In: SJÖSTRÖM, E.; ALÉN, R. (ed.) Analytical methods in wood chemistry, pulping and papermaking. Springer, Heidelberg, pp. 25-148.

Kamdem, D.P.; Pizzi, A.; Jermannaud, A. 2002. Durability of heat-treated wood. Holz als Rohund Werkstoff 60 (1): 1-6.

Kimo, J.W. 1986. Aspectos químicos da madeira de Eucalyptus grandis W.Hill ex Maiden, visando à produção de polpa celulósica. MSc. Dissertation, Universidade Federal de Viçosa, Viçosa, Brazil.

Mohareb, A.; Sirmah, P.; Pétrissans, M.; Gérardin, P. 2012. Effect of heat treatment intensity on wood chemical composition and decay durability of Pinus patula. European Journal of Wood and Wood Products 70 (4): 519-524.

Moura, L.F.; Brito, J.O.; Silva Júnior, F.G. 2012. Effect of thermal treatment on the chemical characteristics of wood from Eucalyptus grandis W. Hill ex Maiden under different atmospheric conditions. Cerne 18 (3): 449-455.

Pessoa, A.M. das C.; Berti Filho, E.; Brito, J.O. 2006. Avaliação da madeira termorretificada de Eucalyptus grandis, submetida ao ataque de cupim de madeira seca, Cryptotermes brevis. Scientia Forestalis 72: 11-16.

Pincelli, A.L.P.S.M.; Brito, J.O.; Corrente, J.E. 2002. Avaliação da termorretificação sobre a colagem da madeira de Eucalyptus saligna e Pinus caribaea var. hondurensis. Scientia Forestalis 61: $122-132$.

Ribeiro-Júnior, J.I. 2001. Análises estatísticas no SAEG. Universidade Federal de Viçosa, Viçosa.

Silvério, F.O. 2008. Caracterização de extrativos de madeira de Eucalyptus e depósitos de pitch envolvidos na fabricação de polpa e celulose. DSc. Thesis, Universidade Federal de Minas Gerais, Belo Horizonte, Brazil.

Sjöström, E. 1993. Wood chemistry: fundamentals and applications. Academic Press, San Diego.

Spiegel, M.R. 1994. Estatística. Pearson Education do Brasil, São Paulo.

Stamm, A.J. 1964. Wood and cellulose science. The Ronald Press: New York.

Sundqvist, B. 2004. Colour changes and acid formation in wood during heating. Ph.D. Thesis, Luleå University of Technology, Luleå, Sweden.

Technical Association of the Pulp and Paper Industry. 1997a. Standard T204 cm: Solvent extractives of wood and pulp.

Technical Association of the Pulp and Paper Industry. 1999. Standard T207 cm: Water solubility of wood and pulp. 
Technical Association of the Pulp and Paper Industry. 2002. Standard T222 om: Acid insoluble lignin in wood and paper.

Technical Association of the Pulp and Paper Industry. 1997b. Standard T264 cm: Preparation of wood for chemical analysis. 